\title{
The INDICARE-model - measuring and caring about participation in higher education's sustainability assessment
}

\author{
Antje Disterheft ${ }^{\mathrm{a}, \mathrm{b}, *}$, Sandra S. Caeiro ${ }^{\mathrm{a}, \mathrm{c}}$, Walter Leal Filho $^{\mathrm{d}}$, Ulisses M. Azeiteiro ${ }^{\mathrm{a}, \mathrm{b}}$ \\ a Department of Science and Technology (DCeT), Universidade Aberta, Rua Braamcamp 90, 1250-052 Lisbon, Portugal \\ ${ }^{\mathrm{b}}$ Centre for Functional Ecology, University of Coimbra, P.O. Box 3046, 3001-401 Coimbra, Portugal \\ ' CENSE, Department of Science and Environmental Engineering, Faculdade de Ciências e Tecnologia, Universidade Nova de Lisboa, Campus da Caparica, \\ 2829-516 Caparica, Portugal \\ d School of Science and the Environment, Manchester Metropolitan University, Chester Street, Manchester M1 5GD, United Kingdom
}

\section{A R T I C L E I N F O}

\section{Article history:}

Received 20 September 2015

Received in revised form

27 November 2015

Accepted 29 November 2015

Available online 25 December 2015

\section{Keywords:}

Higher education

Participation

Sustainability assessment

Model

Indicators

Integrative approaches

\begin{abstract}
A B S T R A C T
The implementation of sustainability in higher education has been advanced over at least the last two decades and brought sustainability assessment on the research agenda of Education for Sustainable Development (ESD) and sustainability science. Participatory approaches have gained increasing attention in these endeavours, but remain often vague and less addressed in sustainability assessment procedures. To fill in this gap, an indicator-based model, INDICARE, was developed that can assist in assessing participatory processes within higher education's sustainability initiatives. The objective of this paper is to introduce and discuss the model's theoretical background, its structure, applicability, and how it can broaden the perspectives on participation and sustainability assessment in the university context.

Embedded in a cross-sectional qualitative research design, the model was developed in iterative stages and was presented and adjusted along six feedback loops, having been presented to 98 persons during conferences, workshops and university meetings. Inspired by biophilic ideas, transformative learning theories and participatory evaluation, INDICARE follows an ecocentric and integrative perspective that places the earth and its community at the centre of attention. A preliminary set of thirty indicators and practices, grouped in three categories of context, process, and transformation, is proposed. The assessment process itself is considered as a thought-provoking exercise rather than as a control tool and emphasizes the interplay of personal reflection and action-oriented outreach. INDICARE intends to invigorate the sustainability debate in higher education, in particular by proposing a more holistic approach to assessment that underlines experiencing the interconnectedness of human-nature relationships, combined with reflective exercises that can respond better to the call for transformation on individual and institutional level.
\end{abstract}

(c) 2015 Elsevier Ltd. All rights reserved.

\section{Introduction}

The debate about the implementation of sustainability principles and values into higher education (HE) has been growing over the past twenty years, and an increasing number of universities have engaged in this implementation process in the most varied ways (Barth, 2013; Lozano et al., 2014). Reinforced by plentiful international conferences and the recent UN-Decade Education

\footnotetext{
* Corresponding author at: Department of Science and Technology (DCeT), Universidade Aberta, Rua Braamcamp 90, 1250-052 Lisbon, Portugal. Tel.: +351922125358.

E-mail addresses: antje.disterheft@gmail.com (A. Disterheft), scaeiro@uab.pt (S.S. Caeiro), walter.leal@haw-hamburg.de (W. Leal Filho), ulisses@uab.pt (U.M. Azeiteiro).
}

for Sustainable Development (ESD) (2005-2014), a specific research field about sustainable universities has emerged (Karatzoglou, 2013; Yarime et al., 2012; Leal Filho et al., 2015). Attempts are being made to distinguish different types of sustainability in HE projects, e.g. categorizing them into (i) greening the campus initiatives/campaigns, with a focus on operational improvements (eco-efficiency), (ii) revision of learning outcomes and curriculum reformulation and (iii) institutional research and development projects (Beringer and Adomßent, 2008). However, despite much progress, sustainability has not become yet an integral part of the university system (Lozano et al., 2013) and further research is needed to tackle the complex challenges and demands within a transition to sustainable universities (Stephens and Graham, 2010).

Within this debate, participatory processes are seen as valuable for a paradigm change towards sustainability, as they can 
contribute towards the debate about how to integrate the sustainability concept into the university culture (Disterheft et al., 2013a; Sterling, 2005). The concept of participation touches areas of institutional governance, social learning and organizational learning, but is presently vaguely defined and is not contextualized yet to sustainability in HE (Barth and Michelsen, 2013; Disterheft et al., 2015a). Motivated by filling this research lacuna, this study is embedded in an on-going cross-sectional project focusing on participatory approaches within sustainability initiatives in HE with the overall objective of developing an assessment tool for these approaches. The research follows a mixed-method design, having used interviews and focus groups with a total of 51 sustainability practitioners in HE from 22 countries (Disterheft et al., 2015a,b). The findings (Disterheft et al., 2015a) suggest that participatory approaches could be better assessed from a social learning and organizational learning perspective (Cebrián et al., 2013), emphasizing non-linear criteria for the quality of the process in terms of depth and meaningfulness, underlining as well the high impact of institutional governance. Following these findings, an indicator-based model for assessing participation in HE's sustainability implementation was developed. The model's development was incited by the call of several sustainability research scholars to explore "new models of engagement to facilitate collective visioning and change towards sustainability amongst different university actors" (Jones, 2013, p. 157 based on Stephens and Graham, 2010).

The model was named INDICARE (read [indi'kare]), standing for indicators or practices that rather care than judge and rather stimulate than strictly measure. A major aim is to offer a more holistic approach by focusing on the quality and transformative character of the participatory process in terms of learning, sharing and new knowledge creation. Since a cultural crisis of perception of the human-nature relationship can be seen as the principal cause for unsustainability (Beringer and Adomßent, 2008; Orr, 2004), INDICARE follows an ecocentric approach (Glasser, 2004; Imran et al., 2014), exploring ideas related to the biophilic university (Jones, 2013).

The main objective of this paper is to introduce and discuss INDICARE, wishing thereby to foster further debate on this research.

\section{Methods}

The model was developed in several stages building upon each other:

- Results from previous qualitative research phases (Disterheft et al., 2015a,b)

- Continuous literature reviews, analysis of existing assessment tools in particular STARS (AASHE, 2014b) and AISHE (Roorda, 2001), as well as critical reflections about ESD in higher education (Disterheft et al., 2012, 2013b)

- A search for existing indicators/practices/criteria focusing on participatory processes led to over 300 indicators, namely from ESD and social learning projects (Di Giulio et al., 2012; Dlouhá et al., 2013; ESD inds, 2011; Mulà, 2011), as well as from community development (Morrissey, 2000; Wenger et al., 2011). These indicators were analysed in depth and grouped into themes and relevance for the INDICARE model, having some been fully integrated in the present model. These indicators' sets were chosen because of their focus on participatory processes that are less represented in sustainability assessment tools. The search also revealed that the term 'indicators' is frequently applied with varying rigorousness, especially within ESD contexts, making comparison more difficult;

- Inspirations during an intensive residential course at the Schumacher College, UK, and repeated application of ecological constellations an embodiment-method based on systemic constellations (Mueller-Christ and Liebscher, 2015);

- Six feedback loops via workshops, meetings and seminars (see Section 4.5), between $0.5 \mathrm{~h}$ and $1 \mathrm{~h}$ of length and consisting of a presentation and/or group work and/or questionnaire (including an evaluation sheet, see Supplementary material). Feedback was collected during conferences, meetings and university visits, having discussed the model with 98 persons: (i) Sept. 2014, WSSD-U 2014, Manchester, UK, (ii) Oct. 2014, Copernicus Alliance Conference, Prague, CZ, (iii) Oct. 2014 ERSCP 2014, Portorož, SL, (iv) Jan. 2015, Alumni/community of practice-meeting Ecological Leadership, Bath, UK; (v) April 2015, Leuphana University, Lueneburg, DE, (vi) June 2016, Universidade Aberta, PT. In all feedback loops, an introductory presentation of the research and model explanation was conducted.

The analysis of the feedback loops helped to simplify the model, to integrate the participants' observations on understandability, usefulness and applicability of the model and to finalize the indicators or practices.

\section{Theoretical context}

The work outlined in this paper is based on a large theoretical framework, which is here outlined by using various strands. Due to their relevance, each strand is briefly explained in the subsequent section.

\subsection{Monitoring and assessing sustainability in higher education}

Monitoring and assessment have become part of the sustainability debate in HE. Various specific tools and rankings have been developed for sustainability assessment in universities (e.g. STARS, AISHE, GASU, among others, see Disterheft et al. (2012) and Lauder et al. (2015) for an overview). While these tools and rankings aim to improve the institutional performance and to make communication about sustainability easier and comparable (Ramos and Caeiro, 2010), having boosted certainly the sustainability discourse in HE, they have also been criticised for their reductionist approaches (Bell and Morse, 2008; Bond and Morrison-Saunders, 2011). Concerns were expressed that sustainability assessment practices in HE run the risk of catering more towards market demands than to societal needs and transformative change, in particular when they focus on competitive benchmarking and quantitative oriented ranking systems (Fadeeva and Mochizuki, 2010; Jones, 2012). There are also concerns that indicators e.g. might simply "serve as legitimization and/or as a means for rational problem solving (...), which would not correspond to the second-order-character of ESD" (Bormann, 2007), representing rather a new form of control than a stimulation for critical reflection. The purpose and focus of indicators has also been vigorously debated (Bormann, 2007; Reid et al., 2006; Tilbury, 2007). ESD indicators emerged from the SD indicators with a specific educational mandate that is based on interdisciplinarity, multi-perspective and participation (Rode and Michelsen, 2008). ESD indicators often display soft instead of absolute indicators, emphasize process and highlight self-assessment, tending "to stimulate learning processes by providing qualitative indicators, which have been actively appropriated and transformed into local knowledge" (Bormann, 2007, p. 7). With these characteristics, ESD indicators correspond more to an ecological paradigm than to a mechanistic paradigm, as the latter rather seeks definitive, detailed, quantitative prescriptive performance indicators (ibid.). 


\subsection{Transformative approaches and ecocentric perspectives}

The call for transformative learning (Mezirow, 1997), made by ESD scholars and other sustainability practitioners in universities (Moore, 2005; Sipos et al., 2008), can also apply to sustainability assessment. Often, there is a call for more participation in the indicator's development (Doody et al., 2009; Santana-Medina et al., 2013), but the participation process remains unconsidered or treated in a reduced manner, e.g. by looking only at the number of attendees (ibid.). The dimensions of participation are therefore to be further explored. To some extent, social learning indicators (Disterheft et al., 2015a; Dlouhá et al., 2013; Mulà, 2011) provide a more distinguished use of participation, differentiating e.g. levels of involvement from informing up to inclusion in decision-making, but with no or little emphasis on the transformative potentials of such interactions. As participatory approaches for sustainability are associated to change, within the assessment of these processes it could be reflected about what kind of learning loops (Argyris and Schoen, 1978, 1996) were fostered, and to what extent values and worldviews were challenged. The assessment process itself is then perceived as a learning and empowerment practice (Barth, 2015; Cousins and Chouinard, 2012; Cousins and Whitmore, 1998).

The ecocentric perspective was found to be useful to address the complex environmental and social crises, as it challenges personal conceptions and relationships, defending to overcome the 'Cartesian worldview', i.e. the separation of the self from nature (Leopold, 1949; Naess, 2008; Roszak, 2001). In order to become an ecological being, Naess (2008) argues that people should be encouraged to 'perform a beautiful act' (ibid.) that results from feeling connected to the natural world. Similarly, the biophilia hypothesis ${ }^{1}$ (Kellert and Wilson, 1995; Wilson, 1984) serves as a basis to Jones to formulate the metaphor of a 'biophilic university' (Jones, 2013). He defines a biophilic university as 'a university which restores an emotional affinity with the natural environment' (ibid., p. 151). This type of university would go beyond fragmented knowledge transfer and include in particular a type of engagement with sustainability not only from a performance-oriented and cognitive perspective, but also from an experiential, emotional and aesthetic angle. Such an approach aligns also with perceiving "sustainability as an organic and evolving construct of our minds "and that "the best we can achieve is to acknowledge the centrality of people and to put participation and the narrative or story of sustainability at the very heart of implementation" (Bell and Morse, 2008, p. 200).

Indicators should therefore predominantly be considered as useful for empowerment rather than for exact measures (ibid.), which constitutes an extremely relevant approach especially within any social setting. Orr proposes that the leading question for sustainability assessment in higher education should be: "Does four years at a particular institution install knowledge, love and competence toward the natural world or indifference and ignorance? Are the graduates of this or that college suited for a responsible life on planet with a biosphere?" (Orr, 2004, p. 90). Universities, as educational institutions and with a mission to serve society, are excellent settings to experiment with these perspectives.

The INDICARE-model aims thereby to respond to the gaps identified above, namely (i) lack of assessment procedures that stimulate reflection and second order learning instead of fear of

\footnotetext{
1 The term biophilia is composed of the two ancient Greek terms bio (life) and philia (Glover et al., 2011), which can be translated as the love or empathy to all living things. Kellert and Wilson (1995) define biophilia as the innately emotional affiliation of human beings to other living organisms. Innate means hereditary and is therefore part of the ultimate human naturell, based on Wilson's argument that emotional affiliation has developed over thousands of years of evolution and human-environment interaction.
}

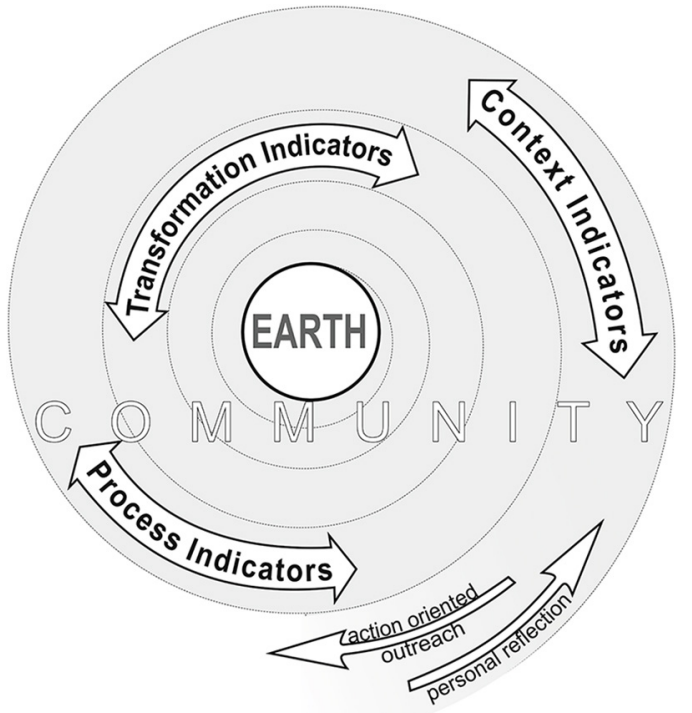

Fig. 1. The INDICARE-spiral.

control, (ii) need for more exploration of dimensions of participation in assessment, (iii) strengthen the transformative potentials of participatory processes, including the perception of the assessment itself as a learning and empowerment practice, (iv) addressing worldviews and personal values by problematizing the separation of the self from nature.

\section{INDICARE: integrating an ecocentric approach to the assessment of participatory processes in sustainability initiatives - proposal of a new model}

"Indicators arise from values (we measure what we care about), and they create value (we care about what we measure)." (Meadows, 1998, p. viii)

Based on the theories and concepts presented above, INDICARE proposes a new approach to looking at universities' sustainability assessment and the engagement of their communities. A working definition for participatory approaches within sustainability initiatives was developed and adapted along the research process (A1).

\subsection{Introducing purpose, structure and applicability}

The INDICARE-model (Fig. 1) is a model developed from a qualitative framework and has the primarily objective to assist in the assessment of participatory processes for sustainability implementation in higher education institutions (HEI). It can be applied to institutions that have already a form of participatory processes in place or under development, or to institutions that are planning to start implementing such a process. The model is therefore overall directed towards the participants themselves and all entities engaged in the process, namely the internal and eventually external interested parties of a HEI. Rather than being a control tool, this model aims to offer participants the possibility to get a clearer picture about the quality of the participatory process and to create meaningful new knowledge. The model may be adapted to the specific context of any sustainability initiative with a participatory character, e.g. sustainability weeks or events, community outreach projects, thematic teaching initiatives, university gardens, among many others (see examples of initiatives in related literature sources, e.g. the publication series Environmental Education, Communication and Sustainability by Peter Lang Publishers, as well 
as the GUNI series on social commitment of universities $1-5$ by Palgrave Macmillan Publishers).

Its structure resembles a spiral, standing for a community with the earth at its centre as a way to mirror the ecocentric perspective. This earth-centeredness is meant as an invitation to (i) direct explicitly the attention of the participatory process towards being in service of the earth, encouraging to allow space for reflection and connecting with the natural world, and (ii) to set also the focus of the assessment purpose towards being in service of the community and the earth. The spiral was chosen because it is a fascinating symbol of nature that has inspired over years philosophers, artists, scientists in many different cultural context and is also considered a symbol of change (Beyer, 2013; Lankester, 1903).

There are two arrows at the entrance of the spiral (Fig. 1): one pointing towards an inward directed process of personal reflection and another one pointing to an outward directed process of action oriented outreach. These arrows refer to the interplay of personal reflection and action that needs to occur to make space for personal growth, shift of perceptions and motivation for behaviour change: "Expanding our awareness of our inner being and the way our inner world connects to the world around us is an essential requirement to creating an environmental sustainable institution and society" (Sharp, 2002, p. 144).

With regard on participation, these arrows represent the inner and outer dimension of transformative learning (Sterling, 2011, p. 20).

This interplay of inner and outer dimension is incorporated into three types of indicators, namely context-, process- and transformation indicators (Sections 4.2-4.4). There are no strict boundaries, as each type of indicators influences and is influenced by the others, and together they stand for non-linear and non-static characteristics of participatory processes. The following criteria were applied for developing the indicators, complemented with a list of practices:

- They express a caring attitude for the well-being of humannature systems, the earth and the community are at the centre of focus (as the wordplay in the model's name suggests, they point something out with care) (Imran et al., 2014);

- They strive for holistic approaches and highlight interrelations (UNESCO, 2014);

- They are adaptable to local context as well as to specific local needs and interests. Before application, it should therefore be assured that they are meaningful to the participants and eventual necessary adjustments be made (Bell and Morse, 2008; Dahl, 2012);

- They attempt to address head, hands and heart (Sipos et al., 2008).

These indicators can be described as 'soft indicators' (Bormann, 2007) with 'loose coupling', since they are "process-oriented, located, indicative and resonant" (ibid.) (in contrast to "tight coupling', which would focus on accountability and performance), and they were not built for ranking or benchmarking as a main purpose Even though they respect only partially the criteria for sustainability indicators (Bell and Morse, 2008; Reed et al., 2006, p. 411) or ESD indicators (Di Giulio et al., 2012; Tilbury, 2007), they fall more into the category of ESD indicators (Section 3).

With its focus on assisting participatory processes and stimulating reflection, INDICARE has been developed for application at micro-level (Rode and Michelsen, 2008). Options for possibly scaling the model up for use at meso-level can be explored, but are not concretized in the present indicators' set. The indicators or practices are to be used in a group process, or can be used by core team members of a sustainability initiative. The three types of indicators - context, process and transformation (Tables A2, A3 and A4) - contain different topics. Each topic is expressed in form of indicators or 'advisable practices' and measured in quantitative or qualitative ways, namely ratios, percentages, checklists (that can include descriptive examples of application) or questionnaires, based and inspired on several bibliographic sources. Overall, the model can be combined with other existing tools, as it may e.g. help to report on STARS in the categories for engagement (see campus and public engagement in STARS (AASHE, 2014b)).

\subsection{Context indicators and practices}

As suggested in systemic approaches (Sharp, 2002), the different parts of a system are interdependent and interrelated. The eleven context indicators or practices (Table A2) suggested in the INDICARE-model address the overall institutional conditions in which a participatory process takes place, focusing on (exemplary) aspects related to (i) a whole-institutional approach (UNESCO, 2014), (ii) governance (Fung, 2006), (iii) education and research (Barth, 2015) and (iv) the aesthetical dimensions (Orr, 2002; Taylor and Enggass, 2009). These dimensions have an impact on the presence or absence of sustainability on campus and influence thereby the ground for participation to happen. Furthermore, they can also point to the importance officially attributed to sustainability and to the existent level of knowledge in this field, e.g. whether inter- and transdisciplinarity (Lang et al., 2012; Parker, 2010) is fostered and regular training in ESD for teaching staff is offered (Barth and Rieckmann, 2012; Schwarzin et al., 2012). In particular, a whole institutional approach is advocated on highest international level (UNESCO, 2014) for accelerating institutional change and implementing sustainability holistically instead of isolated actions supported only by a few groups.

By including also aspects of beauty and aesthetics (Jones, 2013; Krasny and Delia, 2015), it can be reflected on how the physical environment impacts on the perception of human-nature relationships and on the disposition for the academic community to learn and join in for collaborative activities. A pleasant physical environment with well accepted meeting places and where people feel comfortable do not only help developing a sense of place, but are also linked to well-being, constructive learning and community empowerment (Manzo and Perkins, 2006; Taylor and Enggass, 2009).

\subsection{Process indicators}

Process indicators and practices (Table A3) are suggested with a focus on the quality of the process in terms of meaningfulness, depth as well as stimulation for critical reflection and democratic citizenship. They include topics such as (i) facilitation (Macy and Brown, 2014; Virgo et al., 2015), (ii) communication and democratic principles (Habermas, 1985), (iii) the quality of collaboration (Cooperrider et al., 2008; Dragon Dreaming International, 2014), (iv) human-nature relationship and experiencing the interconnectedness of systems (Macy and Brown, 2014; Schultz, 2002).

The overall lack of existing process indicators within sustainability and ESD initiatives (Tilbury, 2011) can be understood as a sign that these are more difficult to develop, since each process is unique and shaped by the context where it takes place (see above). These indicators and practices, thirteen in total, combine different strands of theories and practices that touch relevant aspects to determine the quality of a process and that can inspire to take the process to a deeper level.

Facilitation has become increasingly recognized as determined for the success of participatory processes (Baan et al., 2011; Disterheft et al., 2015b; Virgo et al., 2015). There is an emerging field of new approaches within the sustainability field, mostly based on systems theory and focusing on transformative learning and leadership as a form of facilitation, such as Theory $U$ (Scharmer, 
2008), Dragon Dreaming (Dragon Dreaming International, 2014) and the Art of Hosting (Sandfort and Quick, 2015), with new collaborative methods such as Open Space, World Café, among many others (Muff, 2014), as well as systemic constellations (MuellerChrist and Liebscher, 2015). These approaches are often applied in community projects or local organizations and institutions, including increasingly universities, which are seen as a laboratory for experimentation (Muff, 2014). They can be bottom-up or topdown initiated, but power struggles associated to one or the other approach should become less significant, as in these processes hierarchies are meant to dissolve. ${ }^{2}$ Furthermore, these approaches follow democratic principles and aim to foster democratic citizenship. They are by no means exclusive, and can be combined with other methods suitable for the specific context, but should in general be facilitated by a specially trained facilitator.

To give credit to the quality of communication and the democratic perspective, an 'ideal-discourse indicator' (Appendix Fig. B1) was developed. This indicator is based on Mezirow's categories for an ideal discourse (Mezirow, 1997), who in turn was influenced by Habermas' ideal dialogue (Habermas, 1985), and can help to indicate the quality of communication by assessing the closeness or distance to the ideal discourse. Furthermore, decision-making should strive whenever possible for consensus building, as consensus avoids hierarchies and represents respect and equality better than decision-making through majority voting. Consensus-based decision-making does not mean that there would not be space for dissensus. Critical voices report that a focus on consensus-building in ESD might narrow down the perspectives and leave out uncomfortable dilemma (Læssøe, 2010). Consensus does not necessarily exclude divergences and pluralism. Actually, the communication directed towards dialogue aims to strengthen diversity and calls for a confrontation with the underlying meaning and values of ideas and interests. This confrontation can lead "to an increased understanding of different views as participants become aware that these views are rooted in different contexts of sense and meaning making" (Wals, 2010, p. 144). This increased understanding might be a more probable outcome of a consensus-driven approach than a more time-saving approach to decision-making through voting, when appropriate to the circumstances. Dewey (1916) regards the process of deliberation and communication over collective goals as a democratic public. Interestingly, the audit instrument for sustainability in higher education (AISHE) is uniquely set up on consensus building (Roorda, 2001). Seeley (2010) offers fascinating lessons learnt from his studies about honeybees' decision-making processes, which are also built on consensus, and applies this knowledge in faculty meetings of the Department of Neurobiology and Behaviour at Cornell University. Equally important are considered exercises that help improving effective communication, such as (deep) listening and mindfulness (Rosenberg, 2003; UCLA Mindful Awareness Research Center, 2015; Walters, 2005) which are also encouraged in methods such as Theory $U$ or Dragon Dreaming.

The methods for participatory and collaborative approaches described above share the perception of interconnectedness of human-nature relationships. They are supported by ecopsychological research which showed that experiencing relatedness to nature $^{3}$ is crucial for well-being, as it can cause happiness and "strongly predicts sustainable attitudes and behaviors" (Zelenski and Nisbet, 2014).

\footnotetext{
${ }^{2}$ For further reflection on power and participation, see Gaventa and Cornwall (2006).

${ }^{3}$ In ecological psychology, nature relatedness is defined "as individual differences in cognitive, affective, and experiential connections with the natural environment" (Zelenski and Nisbet, 2014).
}

Returning to the ecocentric approach of INDICARE, it is advocated that participatory processes within sustainability initiatives benefit from allowing space for experiencing connectedness with nature, as it can foster not only the overall individual and collective well-being, but also strengthen intrinsic motivation and values for preserving the ecosystems in balance. Based on Schultz's inclusion with nature-scale (Schultz, 2002), an interconnectedness indicator (Appendix Fig. B2) was developed that can help assessing to what extent participants identify with the perception of interconnectedness of the self and nature. The process of applying this indicator as well as the results obtained at the end offer high potential for discussion and reflection, leading eventually to new perceptions of the human-nature relationships.

\subsection{Transformation indicators}

Transformation has become an increasingly used term in sustainability related context, and higher education is no exception, as many recent publication show (e.g. Adomssent et al., 2008; Barth, 2015; Fadeeva et al., 2014b; Hedlund-de Witt, 2013; Mader et al., 2013; O'Brien et al., 2013; Sharp, 2002; Virgo et al., 2015). According to Macmillan dictionary, transformation means "a change into someone or something completely different, or the process by which this happens" (Macmillan Dictionary, 2015). Fadeeva et al. (2014a, p. 1) make the interesting proposal to look at 'quality' in higher education in terms of "fitness for transformation". Paradoxically, universities as teaching institutions have shown to be rather lethargic than fit in transforming themselves into sustainable universities (Stephens and Graham, 2010). One important aspect might be that often the focus is put on performance (as the many existing ranking system for universities show (Lauder et al., 2015)). Transformative learning research made clear that for transformation to happen the focus should fairly be on mastery and competence development instead of predominantly on performance (Pugh et al., 2010). Performance-focused approaches, besides their advantages depending on the context/aims, can sometimes be motivated by 'avoidence' - the goal is to avoid the demonstration of incompetence - whereas mastery, on the contrary, is associated to the increase of interest (ibid.).

In this sense, the eight transformation indicators and practices of the INDICARE-spiral (Table A4) do not attempt to assess the participatory initiative in terms of performance or competitiveness, but on insights about the quality of the changes that have happened along the journey, focusing on topics such as: (i) shift in perception (Mezirow, 1997,1978),(ii) new cycles of participation/empowerment (Disterheft et al., 2015b), (iii) community cohesion (Fraser et al., 2006; Wenger et al., 2011) and (iv) fun and celebration (Dragon Dreaming International, 2014).

Shifts of perception are at the core of transformative learning, however it is difficult to assess these shifts. With the attempt to gain better insights about the transformative potential of a participatory process, a transformation-compass-indicator (Fig. B3) was developed. This indicator emphasizes the interplay between personal reflection and action-oriented outreach, assuming that the deeper the personal experience is the stronger the commitment to participate in further actions for sustainability.

A successful participatory process strives for empowerment and for eventually new cycles of participation (Disterheft et al., 2015b). A transformation might then be expressed in increased self-confidence through new skills, new connections made and feeling valued, with the potential for new leaders and initiatives to emerge from the process. At the same time, the quality of connections determines the community cohesion and the likeliness to collaborate again (Fraser et al., 2006).

Finally, it has become increasingly recognized that fun and celebration of achievements along the process, even the most little 
Table 1

Feedback loops for model development.

\begin{tabular}{|c|c|c|c|c|c|}
\hline \# & Event type & Place & $n$ & Feedback collection via & $\begin{array}{l}\text { Resulting } \\
\text { modifications }\end{array}$ \\
\hline 1 & Workshop during conference & $\begin{array}{l}\text { World Symposium } \\
\text { Sustainability in Universities } \\
2014 \text { Manchester, United } \\
\text { Kingdom }\end{array}$ & 25 & $\begin{array}{l}\text { Group works ( } 2 \text { rounds of } \\
\text { group works in teams of } 3-4 \\
\text { persons), discussion round } \\
\text { Evaluation sheet }^{\text {a }}\end{array}$ & $\begin{array}{l}\text { Simplification of the } \\
\text { graphical structure }\end{array}$ \\
\hline 2 & Workshop presentation & $\begin{array}{l}\text { Copernicus Alliance } \\
\text { Conference, Prague, Czech } \\
\text { Republic }\end{array}$ & 25 & $\begin{array}{l}\text { Question and discussion round } \\
\text { Evaluation sheet }^{\mathrm{a}}\end{array}$ & $\begin{array}{l}\text { Simplification of the } \\
\text { graphical structure }\end{array}$ \\
\hline 3 & $\begin{array}{l}\text { Presentation in parallel } \\
\text { conference session }\end{array}$ & ERSCP 2014, Portorož, Slovenia & 12 & $\begin{array}{l}\text { Question and discussion round } \\
\text { Evaluation sheet }^{\mathrm{a}}\end{array}$ & $\begin{array}{l}\text { Adaption on } \\
\text { applicability of the } \\
\text { model }\end{array}$ \\
\hline 4 & $\begin{array}{l}\text { Presentation during informal } \\
\text { meeting }\end{array}$ & $\begin{array}{l}\text { Alumni meeting from the } \\
\text { Schumacher's College course } \\
\text { on Ecological Leadership, Bath, } \\
\text { United Kingdom }\end{array}$ & 11 & $\begin{array}{l}\text { Question and discussion round, } \\
\text { field notes }\end{array}$ & $\begin{array}{l}\text { Reflections on the } \\
\text { concept of } \\
\text { transformation, leading } \\
\text { to indicators } \\
\text { development }\end{array}$ \\
\hline 5 & $\begin{array}{l}\text { Presentation during informal } \\
\text { meeting }\end{array}$ & $\begin{array}{l}\text { Leuphana University, } \\
\text { Lueneburg, Germany }\end{array}$ & 6 & $\begin{array}{l}\text { Question and discussion round, } \\
\text { field notes }\end{array}$ & $\begin{array}{l}\text { Changes on some } \\
\text { indicators and figures }\end{array}$ \\
\hline 6 & $\begin{array}{l}\text { Presentation in doctoral } \\
\text { seminar }\end{array}$ & Universidade Aberta, Portugal & 19 & $\begin{array}{l}\text { Question and discussion round, } \\
\text { field notes }\end{array}$ & Present status \\
\hline Total & & & 98 & & \\
\hline
\end{tabular}

Note: $n=$ number of participants.

a See supplementary material.

ones, are an important pillar for transformation in the long-term perspective, because "if it is not playful, it is not sustainable" (Dragon Dreaming International, 2014). Having fun and celebrating are cornerstones of emotional well-being, but often forgotten in sustainability assessment procedures (Bell and Morse, 2008).

\subsection{Feedback loops}

The model went through six feedback loops along the different development stages and was presented in total to 98 persons, namely teachers, researchers, community workers and doctoral students, in five different countries (Table 1)

The evaluation sheets (see Supplementary material) distributed in the first three rounds (37\% response rate) revealed that the purpose of the model was regarded as being clear, and that such a model could be helpful for assessing participatory processes in sustainability implementation. Furthermore, most participants felt personally stimulated for their work and research. The first workshops also helped to understand that the graphical structure of the model (previous versions of Fig. 1) needed to be simplified, as to most participants the structure was only a little or reasonably clear. At that stage, the model had five types of indicators (context, process, output, outcome and impact indicators), and 11 participation-related themes. The structure of the model was then changed along the feedback rounds, and became clearer when some of the previous types of indicators merged into the current transformation indicators. The fourth to sixth feedback round helped adjusting some of the concepts, the indicators' formulation and design, until arriving to the current state.

\section{Discussion - broadening the perspectives for participation and sustainability assessment}

Assessing participation in sustainability implementation is complex, multi-facetted and much more than only counting the number of participants in an event or initiative. INDICARE responds to the calls of scholars for innovative ways in universities' sustainability assessment and institutional transformation (Jones, 2013; McEwen et al., 2010), striving for broadening the perspectives in multiple ways:
- Through an integrative perspective by recognizing the interrelations and links between the context in which the process takes place, the process' design and its execution as well as the transformation that can happen along and after an initiative. The respective indicators and practices can help to get a clearer picture of how e.g. the governance structures or circumstances of meeting places (context) impact the communication (process) and community cohesion (transformation) before, during and after a participatory approach. Identifying and understanding these interrelations make part of systems thinking and have the potential to shake up the current (western) educational system, as they may lead to ask the necessary deeper questions for a paradigm change (Orr, 2004). Phillips (2009, p. 209) makes clear that "the educational system [...] is at the heart of our current unsustainable society, being both its product and its creator. Embodied in all its aspects, from the buildings to staff selection and from catering to curriculum planning are values and assumptions which are in themselves unsustainable". If participation in sustainability implementation shall go beyond campus greening in forms of recycling, better waste separation or electricity switching off-campaigns, participatory approaches should allow space for asking these deeper questions. In this sense, the integrative perspective applied in the INDICARE-model is also expressed through emphasizing the interplay of personal reflection and action-oriented outreach. To the authors' knowledge, this aspect has not been captured so far neither in ESD nor in sustainability assessment, and therefore the suggested indicators in particular the transformation-compass indicator (Fig. B3) - can offer a fresh look.

- By emphasizing an empowerment-perspective, the purpose of assessment is directed away from control, benchmarking or accountability to the benefit of the individual and the collective, in form of personal and community growth, manifested e.g. in community cohesion, increase of trust, new collaborations, new skills and the emergence of new leaders (Bell and Morse, 2008). This perspective is also closely connected to developing one's citizenship skills and rethinking the practice of democracy (Wals, 2010).

- The ecocentric perspective invites to consider more systematically the human-nature relationship and to raise awareness for the interconnectedness of societal systems and ecosystems 
(Imran et al., 2014). This perspective is incorporated in the graphical structure of the model and along the three indicators' types in different ways, mirroring the working definition for participatory processes (A1). The INDICARE-model can be seen as a response to Orr's suggestion of adopting another direction in sustainability assessment than many assessment practices currently do, in particular rankings. The suggested indicators and practices in this model can be helpful to track opportunities for reconnecting with the natural world, e.g. the interconnectedness-indicator (Fig. B2) and the transformation-compass indicator (Fig. B3), but also the indicators for beauty and aesthetical dimensions. The ecocentric perspective challenges also to ask whether the community and the earth are at the centre of the sustainability implementation and its assessment, or whether there are other purposes, such as marketing and greening the institutional image, distorting this goal. This perspective does not only help to see the larger picture of sustainability, often associated also to 'strong' or 'deep' sustainability (Beringer and Adomßent, 2008; Imran et al., 2014), but strengthens likewise the capability of asking questions like 'Who am I?' and 'How do I want to relate to the world?' (Roszak, 2001). Seeking those kind of answers may take one on an ecological approach to being in the world (Naess, 2008) and to strive for stimulating all forms of knowing (cognitive, emotional, aesthetical), like a biophilic university would foster (Jones, 2013).

- The transformative perspective is characterized by using assessment for reflection on values and assumptions, tracking the transformative potentials of a participatory process on individual, collective and institutional level. By adopting a transformative perspective in this model, participatory processes and their assessment can help guiding this transformation through fostering transformative learning, making the necessary space for new values to arise. This perspective is closely linked to the integrative perspective explained above, and by following this perspective, INDICARE responds to the call for putting systemic transformation on the priority level of higher education's research agendas (Stephens and Graham, 2010; Sterling, 2005), as it is also expressed in the Rio + 20 treaty for higher education: "\#1: To be transformative, higher education needs to transform itself” (Copernicus Alliance, 2012). While acknowledging that important steps were done in redirecting the attention towards transformation, as the Rio +20 treaty or other initiatives (Barth, 2015) show, more energy and effort is needed to continue the path in a new direction. A transformative perspective would e.g. imply changes in the performance-oriented assessment mostly in place. When the focus lies on demonstrating good performance (i.e. being on the top of ranking lists), in order to avoid a lower or even incompetent reputation, or having legal troubles, there is only little space for transformative experience (Pugh et al., 2010). The energies may then be directed more to 'putting up a good show' than to transformative change, which can be observed in cases of 'greenwashing'. For genuine transformation to happen, the interplay of an inward and outward directed process, as suggested in the INDICARE-spiral, needs to be strengthened and exercised: "The work of institutional transformation is a calling to undertake a parallel journey within ourselves. As we seek to change what is around us we must seek to change what is within us also" (Sharp, 2002, p. 144). Participatory approaches, if appropriately designed, have the potential to foster such kind of a transformative journey towards sustainability and make the links between individual and collective growth.

By following these perspectives, the INDICARE-model intents to offer a contribution to Bell and Morse's (2008) advice of perceiving sustainability as an evolving construct of our minds. There will be no final answer of how a sustainable university looks like and no final definition to identify such an institution, even though characteristics have been identified (Beringer and Adomßent, 2008). Similarly, indicators for assessing participatory approaches within sustainability implementation will continue to evolve and their reference frameworks can be negotiated, verified and changed. By placing the earth and the academic community at the centre of attention, the overall purpose of sustaining life may be an important focus in this continuous search.

The use of INDICARE should be accompanied by empirical research in order to understand better the effects of application and to verify to what extent knowledge transfer is taking place (Bormann, 2007). Ideally, transformative processes should be followed-up on a long-term perspective, beyond the suggested six months in this model, in order to gain better insights about the effectiveness and long-lastingness of undergoing changes. In this regard, HEI are faced with a particular challenge, as at least one of the main interest groups - the students - usually only stay for a relatively short period of time in their institution.

Similarly to other models, INDICARE has its limitations. For instance with regard on the complex dimensions of participation, this model cannot be considered complete, as other focal points for assessment are imaginable, and an integration in other existing sustainability assessment tools can be desirable.

Interrelations between the context and the quality of a participatory process require also further research, as there can be tensions or contradictions regarding the influence of the context on the process itself, as e.g. not necessarily modern optimal facilities may include space for participation.

The developed set of indicators and practices lack a deeper action research approach, as the set ideally would have been developed together with participants, as it is good practice in this field (Bell and Morse, 2008; Dahl, 2012). Even though the model was discussed with 98 persons, not all ideas and aspects could be discussed in every detail, as the topics presented were very complex and time consuming to discuss. The feedback loops presented in Section 4.5 could not be extended at the current stage of research due to the time constraints of the participants, but also due the high organizational efforts implied in conducting the discussion rounds.

In addition, the presented indicators and practices are not biasfree, as subjectivity is fostered in some cases in order to enhance the reflective process. Representativeness constitutes another limitation challenge, as this model hardly could credibly assist in an assessment with over thousands of students, staff and faculty. Working with larger groups, e.g. over 100 persons to name a number, is possible, but requires even more attention from the facilitators' side. Since facilitation can be regarded as a key element for success (Disterheft et al., 2015b), the suggested indicators \#P1.1-1.3 may be used as well in preparing and executing the assessment practice. Concrete experiences on applicability are still needed, and the indicators or practices are neither tested nor indexed yet. In the continuation of this research, it is envisioned to apply and test the model in a HE case study, and investigate together with participants how the assessment is viable in practice. The indicators shall be examined on their strengths and weaknesses, in order to verify how well they can achieve the purpose they were built for. Furthermore, it shall be investigated if the set of indicators and practices can be aggregated and scaled up to meso-level.

\section{Conclusions}

Higher education's sustainability implementation has been advanced over at least the last two decades and brought sustainability assessment on the research and policy agenda of ESD and sustainability science. This agenda calls for innovative and more transformative approaches than reductionist practices, in order to respond better to the need for an institutional learning 
culture that envisions dialogue and change. Universities are seen as ideal fields for experimenting with new participatory processes to foster a transition to a more sustainable paradigm, but the complexity of participation has not been captured yet in existing sustainability assessment tools. As an outcome of a cross-sectional qualitative research project, the INDICARE-model was developed and shall contribute to fill this gap. Its indicators and practices are intended to invigorate the sustainability debate in higher education, in particular by proposing a more holistic approach to assessment that emphasizes experiencing the interconnectedness of human-nature relationships, combined with reflective exercises that can respond better to the call for transformation on individual and institutional level. Along the research, the authors reflected deeply on the following questions:

- What is the purpose of current higher education?

- How can the paradigm change for sustainability truly be fostered?

Inspired by Daniella Meadows' observation "We measure what we care about" (Meadows, 1998), a set of thirty indicators or practices point out to participation and sustainability implementation with care for the entire academic community, interweaving the context and the process design with potentials for individual and collective transformation. Making linkages to ideas about a biophilic university (Jones, 2013), the INDICARE-model broadens the perspectives on participation and invites to explore new paths towards sustainable universities as well as their assessment. This exploration should include asking deeper questions about underlying values and assumptions rooted in the current education system and allow space for unconventional approaches that may break with traditional rationality. Perceiving the assessment process itself as a thought-provoking opportunity for learning constitutes one of the many opportunities to transform higher education. In the following research step, the proposed model will be tested in practice, in order to adjust its indicators and practices. The thirty-two indicators and practices are just a first preliminary set. Other indicators or practices can be added and up-dated, as well as other possible measurements. The proposed model has its limitations as stressed earlier in the manuscript, and still needs to be tested and validated. In the next research steps, INDICARE will be examined in practice, in order to adjust its indicators and practices.

As this research focuses on HE, the model was developed for application in higher education institutions, but can also be adapted to other organization or contexts.

\section{Acknowledgements}

The authors wish to thank all participants in this research, as well as all colleagues and the anonymous reviewers of this journal who provided important feedback on this work. The main author is especially grateful to the Schumacher College, UK, as well as to Christian Rammel for his valuable comments on an earlier version of this manuscript.

\section{Appendices.}

\section{A1. Working definition for participatory approaches}

By participatory processes within sustainability initiatives we understand the engagement of all critical stakeholder groups/interested parties into a deliberative process design to define goals, responsibilities and actions towards the transition to a more sustainable university now and in future. A participatory process directed towards sustainability recognizes the interdependence of human-nature systems, thriving for personal and collective development through diverse forms of knowing that include the cognitive, emotional and aesthetical dimensions, making space for holistic experiences that can stimulate reflection, critical thinking and a caring attitude towards the human-nature systems.

Table A2

Context indicators and practices.

Main characteristics

These indicators or practices assess the context, i.e. the presence of the topic of sustainability in the institution. The overall presence of sustainability predetermines the conditions and influences the ground for participation in sustainability initiatives. They can point to the importance attributed to sustainability and to the level of knowledge about sustainability and ESD existent (e.g. whether the topic has become part of the institution or is only shared by a few groups of interest). For each topic several indicators or practices with the respective possible forms of measurement are provided. The main name or focus of each indicator/practice is highlighted in bold, explanations are written in italic.

\begin{tabular}{|c|c|c|c|c|}
\hline Topic & \# & Indicator/practice & Possible measurements & Sources \\
\hline $\begin{array}{l}\text { Whole institution } \\
\text { approach for } \\
\text { sustainability } \\
\text { implementation (e.g. } \\
\text { addresses the } 5 \\
\text { dimensions of a HEI: } \\
\text { Education, Research, } \\
\text { operations, external } \\
\text { community and } \\
\text { assessment and } \\
\text { reporting) }\end{array}$ & $\mathrm{C} 1$ & $\begin{array}{l}\text { The university follows a whole } \\
\text { institution approach for } \\
\text { sustainability implementation }\end{array}$ & $\begin{array}{l}\text { - Checklist: } \\
\text { (i) yes } \square \\
\text { (ii) not yet, but in progress } \\
\text { (iii) no } \square \\
\text { if (i) and (ii) are checked examples should be provided } \\
\text { Based on UNESCO } 37 / C \text { resolution } 12 \text { (UNESCO, 2014) } \\
\text { Choose yes, when: } \\
\text { The institution applies fully a sustainability strategy } \\
\text { that seeks to align: } \\
\text { - teaching content as well as } \\
\text { - campus and facility management as well as } \\
\text { - the cooperation with community stakeholders } \\
\text { towards the principles of sustainable development } \\
\text { Choose not yet, but in progress when: } \\
\text { The institution is in a development process of a } \\
\text { sustainability strategy that seeks to follow a } \\
\text { whole-institutions approach, being in application at } \\
\text { least one of the strategic listed above. } \\
\text { Choose no, when: } \\
\text { The institution endeavours sustainability only in some } \\
\text { areas of its institution, with no connection among } \\
\text { these efforts }\end{array}$ & $\begin{array}{l}\text { Adomssent et al. (2008) } \\
\text { Cortese (2003) } \\
\text { Koester et al. (2006) } \\
\text { Lozano (2006) }\end{array}$ \\
\hline
\end{tabular}


Main characteristics

These indicators or practices assess the context, i.e. the presence of the topic of sustainability in the institution. The overall presence of sustainability predetermines the conditions and influences the ground for participation in sustainability initiatives. They can point to the importance attributed to sustainability and to the level of knowledge about sustainability and ESD existent (e.g. whether the topic has become part of the institution or is only shared by a few groups of interest).

For each topic several indicators or practices with the respective possible forms of measurement are provided. The main name or focus of each indicator/practice is highlighted in bold, explanations are written in italic.

\begin{tabular}{|c|c|c|c|c|}
\hline Topic & \# & Indicator/practice & Possible measurements & Sources \\
\hline Governance & $\mathrm{C} 2.1$ & $\begin{array}{l}\text { There exist policies for } \\
\text { sustainability implementation: } \\
\text { - specific declarations (such } \\
\text { as the Earth charter or the }\end{array}$ & $\begin{array}{l}\text { - Checklist for each indicator/practice: } \\
\text { (i) yes } \square \\
\text { (ii) not yet, but in progress } \square \\
\text { (iii) no } \square\end{array}$ & $\begin{array}{l}\text { Earth Charter Initiative } \\
\text { (2010) } \\
\text { Copernicus Alliance (2012) } \\
\text { ESD inds (2011) }\end{array}$ \\
\hline
\end{tabular}

Rio +20 Treaty (among many if (i) or (ii) are checked examples should be provided others)) have been signed;

- a specific institutiona

sustainability strategy is in place

C.2.2 Organizational structure of the institution provides space for sustainability implementation

C.2.2.1 A sustainability office exists (and is preferably supported by the top management of the university)

C2.2.2 Specifically trained staff in ESD are part of the faculty

C2.2.3 Participation of the academic community in relevant organs of the institution valued and supported officially through inclusive and open governance structures $(e . g$. committees/advisory boards/representative organs of the institution, e.g. following criteria as described in STARS or similar)

C2.2.4 Institutional decision-making processes provide for equal and just representation

\section{Education and}

Sustainability has been research integrated into the whole curricula and is part of the institution's research agenda

C3.2 ESD training for staff (educators) from all disciplines and faculties is offered (e.g. UE4SD project)

The spaces available to meet (can/should refer to indoor and outdoor) are pleasant and promote interaction rather than passivity
- Checklist for each

indicator/practice:

(i) yes $\square$

(ii) not yet, but in progress

(iii) no $\square$

if (i) or (ii) are checked examples

should be provided

UNESCO (2014)

Brinkhurst et al. (2011)

Disterheft et al. (2015b)

Barth and Rieckmann (2012)

UNESCO (2014)

STARS (AASHE, 2014a) and general literature about governance and sustainability in HEI

- A summarizing diagram of representative organs and their composition is elaborated by the team leaders in order to review the regular election procedures with respect to transparency, equality, gender

\section{Questionnaire/focus group}

Participants indicate their level of satisfaction with current structures in place and their understanding of inclusive and transformative governance structures, e.g. on a scale from 1 to 5 or 1 to 7

\section{- Checklist:}

(i) yes $\square$

(ii) not yet, but in progress $\square$

(iii) no $\square$

if (i) or (ii) are checked examples should be provided - Checklist:

Training is open to all staff members and takes place regularly, e.g.

(i) yes, 1 to 2 times per year $\square$

(ii) not yet, but one training already took place in the past and another is planned in the current academic year $\square$

(iii) no training exists yet $\square$

if (i) or (ii) are checked examples should be provided

- Ratio or percentage of participants in trainings against total number of staff

\section{- Questionnaire/focus group}

- Participants indicate to what extent they fee comfortable in the places to meet (e.g. on a scale from 1 to 5 or 1 to 7 )

- Participants indicate how well these places stimulate interaction according to their individual perception (e.g. on a scale from 1 to 5 or 1 to 7 )
Fung (2006)

ESD inds (2011, Indicator \#16)

Barth and Rieckmann (2012)

Lidgren et al. (2006)

Schwarzin et al. (2012)

UE4SD (2014)

Sterling (2012)

Orr (2002)

Taylor and Enggass (2009) 
Main characteristics

These indicators or practices assess the context, i.e. the presence of the topic of sustainability in the institution. The overall presence of sustainability predetermines the conditions and influences the ground for participation in sustainability initiatives. They can point to the importance attributed to sustainability and to the level of knowledge about sustainability and ESD existent (e.g. whether the topic has become part of the institution or is only shared by a few groups of interest).

For each topic several indicators or practices with the respective possible forms of measurement are provided. The main name or focus of each indicator/practice is highlighted in bold, explanations are written in italic.

\begin{tabular}{|c|c|c|c|c|}
\hline Topic & $\#$ & Indicator/practice & Possible measurements & Sources \\
\hline & C4.2 & $\begin{array}{l}\text { The spaces available to meet } \\
\text { (e.g. auditory, theatre, university } \\
\text { garden, park/loan) are well } \\
\text { accepted and are used } \\
\text { frequently in daily academic } \\
\text { life by a mixture of different } \\
\text { groups (faculty, students, } \\
\text { non-teaching staff) }\end{array}$ & $\begin{array}{l}\text { - Questionnaire: } \\
\text { - Participants indicate their individual level } \\
\text { of acceptance (e.g. on a scale from } 1 \text { to } 5 \text { or } 1 \text { to } 7 \text { ) } \\
\text { - Observation: } \\
\text { Team leaders observe how meeting places are used in } \\
\text { daily academic life }\end{array}$ & \\
\hline
\end{tabular}

Table A3

Process indicators and practices.

Main characteristics

These indicators and practices assess the quality of the process in terms of meaningfulness, depth as well as stimulation for critical reflection and democratic citizenship. For each topic several indicators or practices with the respective possible forms of measurement are provided. The main name or focus of each indicator/practice is highlighted in bold, explanations are written in italic.

\begin{tabular}{|c|c|c|c|c|}
\hline Topic & $\#$ & Indicator/practice & Possible measurements & Sources \\
\hline Facilitation & P1.1 & $\begin{array}{l}\text { Before starting the process, it was } \\
\text { reflected how the facilitation will be } \\
\text { carried out (e.g. with specifically } \\
\text { trained facilitator, or university team } \\
\text { member or external contributor or a } \\
\text { mix) }\end{array}$ & $\begin{array}{l}\text { - Checklist: } \\
\text { (i) yes } \square \\
\text { (ii) not yet, but in progress } \square \\
\text { (iii) no } \square \\
\text { if (i) and (ii) are checked, team leaders provide } \\
\text { a short descriptive justification for the choices } \\
\text { made: } \\
\text { - On the facilitator } \\
\text { - On the participatory methods }\end{array}$ & $\begin{array}{l}\text { Literature on } \\
\text { facilitation (e.g.: Virgo } \\
\text { et al., 2015; Macy and } \\
\text { Brown, 2014, good } \\
\text { support for checking } \\
\text { facilitator's capacities } \\
\text { for SD in Baan et al., } \\
2011, \text { p. 52) }\end{array}$ \\
\hline
\end{tabular}

P1.2 Appropriate participatory methods were carefully chosen

P1.3 Level of satisfaction of participants with the facilitation along the process

Communication and democratic principles

P2.1

\section{Ideal discourse-indicator (see} Appendix A1, Participants asses the closeness/distance towards the ideal discourse)

P2.2 Deep listening and mindfulness exercises:

- The participatory process

allows space and moments

of collective silence

- Specific exercises are applied to

become aware and reflect on

voices of judgement, cynicism

and fear

- There is time to deeply listen to the natural environment

P2.3 The process is inclusive and open to all interested parties.

(e.g. the process allows for representing absent voices through democratic trusteeships (Thompson, 2010) or systemic constellations (Mueller-Christ and Liebscher, 2015))

- The Earth is represented

- Future students are represented

- Future collaborators are represented

P2.4 Decision-making processes thrive for consensus building
- On the participatory methods
A short profile of the facilitator should be added

Questionnaire/focus group during and/or at the end of the initiative (participants indicate their level of satisfaction, e.g. on a scale from 1 to 5 or 1 to 7)

Using Appendix A1 for

(i) Individual mapping (on prepared sheet), or

(ii) Group mapping (enlarged prepared sheet on a wall where participants can stick glueing points).

The indicator can be combined with selected ESD inds-indicators

- Checklist:

(i) yes $\square$

(ii) not yet, but in progress $\square$

(iii) no $\square$

if (i) or (ii) are checked, examples should be provided, such as specific techniques or procedures for deep listening that were agreed upon (e.g. a specific item/procedure (e.g. ring a bell) is chosen by the group; see 'pinakarri' in Dragon Dreaming)

- Team leaders elaborate a diagram of all relevant groups and cross-check the possibilities for each group to access information and to join in

- Checklist:

Possibilities to include absent voices have been tested:

(i) yes $\square$

(ii) not yet, but in progress $\square$

(iii) no $\square$

if (i) or (ii) are checked, examples should be provided

- Checklist:

(i) yes $\square$
(ii) not yet, but in progress $\square$
(iii) no $\square$

If (i) or (ii) are checked, examples should be provided; if (iii) is checked, a short explanation should be given why consensus building was not possible
Mezirow (1997)

ESD inds (2011)

Dragon Dreaming International (2014) Theory U (Scharmer, 2008).

Jongbloed et al. (2008)

Reed et al. (2009)

Shiva (2005)
Roorda (2001)

Seeley (2010)

Seeds for Change (2013) 
Main characteristics

These indicators and practices assess the quality of the process in terms of meaningfulness, depth as well as stimulation for critical reflection and democratic citizenship. For each topic several indicators or practices with the respective possible forms of measurement are provided. The main name or focus of each indicator/practice is highlighted in bold, explanations are written in italic.

\begin{tabular}{|c|c|c|c|c|}
\hline Topic & \# & Indicator/practice & Possible measurements & Sources \\
\hline \multirow[t]{3}{*}{$\begin{array}{l}\text { Quality of } \\
\text { collaboration }\end{array}$} & P3.1 & $\begin{array}{l}\text { Specific participatory methods are } \\
\text { applied to offer time for collective } \\
\text { dreaming and creating in which } \\
\text { outcomes remain undefined }\end{array}$ & $\begin{array}{l}\text { - Checklist: } \\
\text { (i) yes } \square \\
\text { (ii) not yet, but in progress } \square \\
\text { (iii) no } \square \\
\text { If (i) or (ii) are checked, examples should be } \\
\text { provided }\end{array}$ & $\begin{array}{l}\text { Appreciative Inquiry } \\
\text { (Cooperrider et al., 2008) } \\
\text { Dragon Dreaming } \\
\text { International (2014) } \\
\text { Theory U (Scharmer, 2008) } \\
\text { Work by Joanna Macy }\end{array}$ \\
\hline & P3.2 & $\begin{array}{l}\text { Participants feel and perceive } \\
\text { themselves as being part of something } \\
\text { what they co-initiated and co-created }\end{array}$ & $\begin{array}{l}\text { - The group elaborates a storyboard of the process } \\
\text { (see also P4.3) } \\
\text { - Questionnaire (Participants indicate their level } \\
\text { of agreement, e.g. scale from } 1 \text { to } 5 \text { or } 1 \text { to } 7 \text { ) }\end{array}$ & (Macy and Brown, 2014) \\
\hline & P3.3 & $\begin{array}{l}\text { Development of practical skills and } \\
\text { ESD competences is strengthened in } \\
\text { the process }\end{array}$ & $\begin{array}{l}\text { - Questionnaire/focus group during and/or at the } \\
\text { end of the initiative (participants indicate their } \\
\text { level of agreement, e.g. on a scale from } 1 \text { to } 5 \text { or } 1 \\
\text { to } 7 \text { and provide examples of skills and } \\
\text { competences that they could develop) }\end{array}$ & $\begin{array}{l}\text { Mochizuki and Fadeeva } \\
\text { (2010) } \\
\text { Rieckmann (2012) }\end{array}$ \\
\hline \multirow[t]{3}{*}{$\begin{array}{l}\text { Human-nature } \\
\text { relationship and } \\
\text { experiencing } \\
\text { interconnected- } \\
\text { ness of } \\
\text { systems }\end{array}$} & P4.1 & $\begin{array}{l}\text { Part of the process takes people } \\
\text { outdoor }\end{array}$ & $\begin{array}{l}\text { - Checklist: } \\
\text { (i) yes } \square \\
\text { (ii) not yet, but in progress } \square \\
\text { (iii) no } \square \\
\text { If (i) or (ii) are checked, examples should be } \\
\text { provided }\end{array}$ & $\begin{array}{l}\text { Dragon Dreaming } \\
\text { International (2014) } \\
\text { Work by Joanna Macy } \\
\text { (Macy and Brown, 2014) } \\
\text { Presencing Institute (2015) }\end{array}$ \\
\hline & P4.2 & $\begin{array}{l}\text { Interconnectedness-indicator (see } \\
\text { Appendix A2; people have been invited } \\
\text { to reflect where they position } \\
\text { themselves in relation to the natural } \\
\text { world) }\end{array}$ & $\begin{array}{l}\text { Using Appendix A2 for } \\
\text { - (i) Individual mapping (on prepared } \\
\text { sheet), or } \\
\text { - (ii) Group mapping (enlarged prepared } \\
\text { sheet on a wall where participants can stick } \\
\text { glueing points) } \\
\text { Evtl. changes can be tracked over time }\end{array}$ & Schultz (2002) \\
\hline & P4.3 & $\begin{array}{l}\text { Process design of participation follows } \\
\text { cycles inspired by nature (spring, } \\
\text { summer, autumn, winter) with phases } \\
\text { that are more inward directed (time } \\
\text { for contemplation and pauses like in } \\
\text { autumn and winter) and others that } \\
\text { are more outward directed, with } \\
\text { actions (like spring and summer) } \\
\text { The process strives for balancing } \\
\text { head-hand-heart }\end{array}$ & $\begin{array}{l}\text { - Checklist: } \\
\text { (i) yes } \square \\
\text { (ii) not yet, but in progress } \square \\
\text { (iii) no } \square \\
\text { If (i) or (ii) are checked, examples should be } \\
\text { provided. Examples of evidence may include e.g. } \\
\text { the use of specific methods, such as: } \\
\text { - Appreciative inquiry and/or } \\
\text { - Journaling } \\
\text { - Meditative walks } \\
\text { - Celebration and space for creativity, } \\
\text { eventually making a collage or a story } \\
\text { board of the different approaches chosen to } \\
\text { include inward and outward directed } \\
\text { phases, using e.g. the INDICARE spiral }\end{array}$ & $\begin{array}{l}\text { Macy and Brown (2014) } \\
\text { Sipos et al. (2008) }\end{array}$ \\
\hline
\end{tabular}

\section{Table A4}

Transformation indicators and practices.

Main characteristics

These indicators and practices indicate changes that have been taken place on individual, group and institutional level

\begin{tabular}{|c|c|c|c|c|}
\hline Topic & \# & Indicator/practices & Possible measurement & Sources \\
\hline Shift in perceptions & $\mathrm{T} 1$ & $\begin{array}{l}\text { Transformation } \\
\text { compass-indicator (see } \\
\text { Appendix A3) }\end{array}$ & $\begin{array}{l}\text { Using Appendix A3 for } \\
\text { (i) Individual mapping on prepared sheet, or } \\
\text { (ii) Group mapping (prepared sheet on a } \\
\text { wall where participants can use sticky }\end{array}$ & $\begin{array}{l}\text { Mezirow (1997) } \\
\text { Macy and Brown (2014) } \\
\text { Dragon Dreaming } \\
\text { International (2014) }\end{array}$ \\
\hline
\end{tabular}
dots)

The indicator should be measured at the end of the process of participation + some time afterwards (e.g. after 6 months)

\section{New cycles of} participation/empowerment ncreased self-confidence through new skills, experiences, networks
People feel more valued Emergence of new leaders/initiatives
Questionnaire or focus group at the end of the project +6 month afterwards. Participants indicate, e.g.

- the increase of self-confidence (e.g. on a scale from 1 to 5 or 1 to 7 ) and responsible factors

- the extent of feeling valued (e.g. on a scale from 1 to 5 or 1 to 7 from not feeling valued to feeling highly valued)

Team leaders provide a description of examples of new born initiatives that resulted from the process
Disterheft et al. (2015a,b)

ESD inds (2011)

Morrissey (2000) 
Table A4 (Continued)

Main characteristics

These indicators and practices indicate changes that have been taken place on individual, group and institutional level

\begin{tabular}{|c|c|c|c|c|}
\hline Topic & \# & Indicator/practices & Possible measurement & Sources \\
\hline & $\mathrm{T} 2.4$ & $\begin{array}{l}\text { Impact on governance } \\
\text { structures }\end{array}$ & $\begin{array}{l}\text { - Checklist: } \\
\text { (i) yes } \square \\
\text { (ii) not yet, but in progress } \square \\
\text { (iii) no } \square \\
\text { if (i) or (ii) are checked, descriptive examples } \\
\text { should be provided where applicable. Possible } \\
\text { cases could be } \\
\text { - new institutional policies, or } \\
\text { - better integration of stakeholder groups in } \\
\text { decision-making (e.g. students being } \\
\text { included in decisive organs) }\end{array}$ & \\
\hline
\end{tabular}

Community cohesion

T3

\section{Fun and} celebration
People confirm that they got to know each other better, e.g. they refer to:

(i) the quality of new connections made, and/or

(ii) engagement in meaningful conversations, and/or

(iii) likeliness to collaborate again/to do something together (within the community)

Fun and celebrations activities are organized regularly along the initiative, celebrating achievements along the process (not only at the end)

T4.2 People like to join in for celebration of the collective achievements
- Specific Group exercises are facilitated that are directed towards capturing the quality of connections, e.g. making together a picture of knots/a web representing the (new types of) links in the community

Can be combined with T1 Transformation compass

- Questionnaire/focus group: Participants indicate in which ways they got to know each other better

\section{- A photo-collage is elaborated and} participants indicate their level of fun on a scale from 1 to 5 or 1 to 7 Interactive group exercises are facilitated to check for happiness and well-being

- Ratio of number of participants along the initiative against participants in celebration/festivities

- Questionnaire: Participants indicate if and why they like to join in for celebration
Wenger et al. (2011) Hart and Wolff (2006)

Sources about group processes (e.g. Virgo et al., 2015)
$\Rightarrow$ The closer to the ideal discourse, the higher the quality of communication (based on Mezirow's ideal discourse (Mezirow, 1997))

\section{Possible measurement:}

(i) Individual mapping on prepared sheet, or

(ii) group mapping (prepared sheet on a wall where participants can use sticky dots).

Note: To reflect on the quality of communication, this indicator can be combined with ESD indsindicators (ESD inds, 2011):

- People respect, appreciate and find ways to understand the differences in others

- People feel that they have an equal opportunity to express their opinions

- People treat each other with kindness

- People speak courteously to each other

- People treat each other with equity and fairness

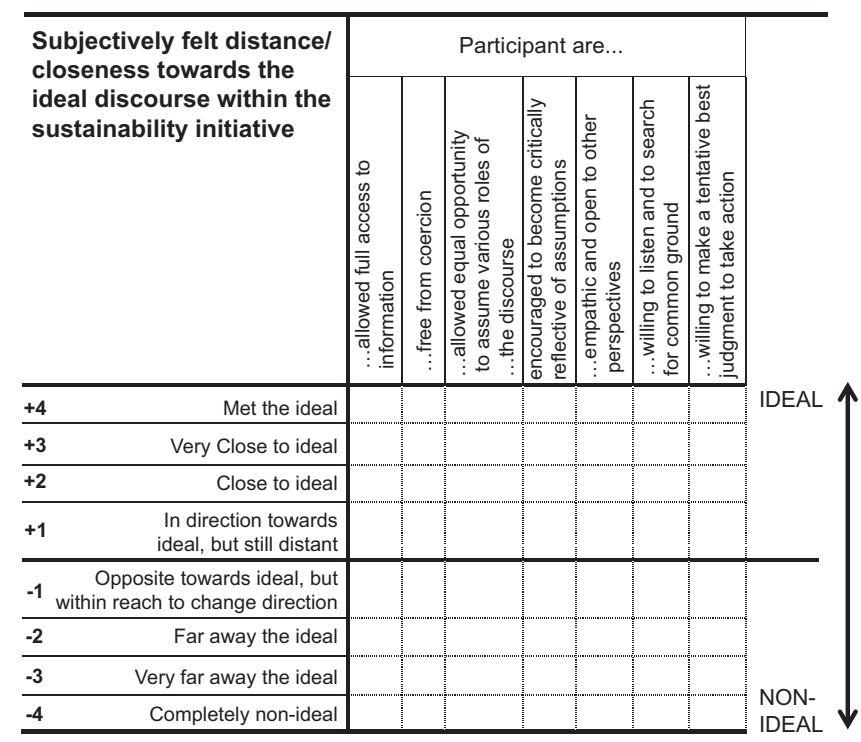

Fig. B1. Ideal-discourse indicator. 
$\Longrightarrow$ The closer the participant positions herself/ himself towards or into the center of the spiral, the more she/he identifies with the perception of the interconnectedness of the self and nature (adapted from Schultz, 2002).

This identification can be used for further reflection and discussion.

\section{Possible measurement:}

(i) Individual mapping on prepared sheet, or

(ii) group mapping (prepared sheet on a wall where participants can use sticky dots).

Eventual changes can be tracked over time / along the process

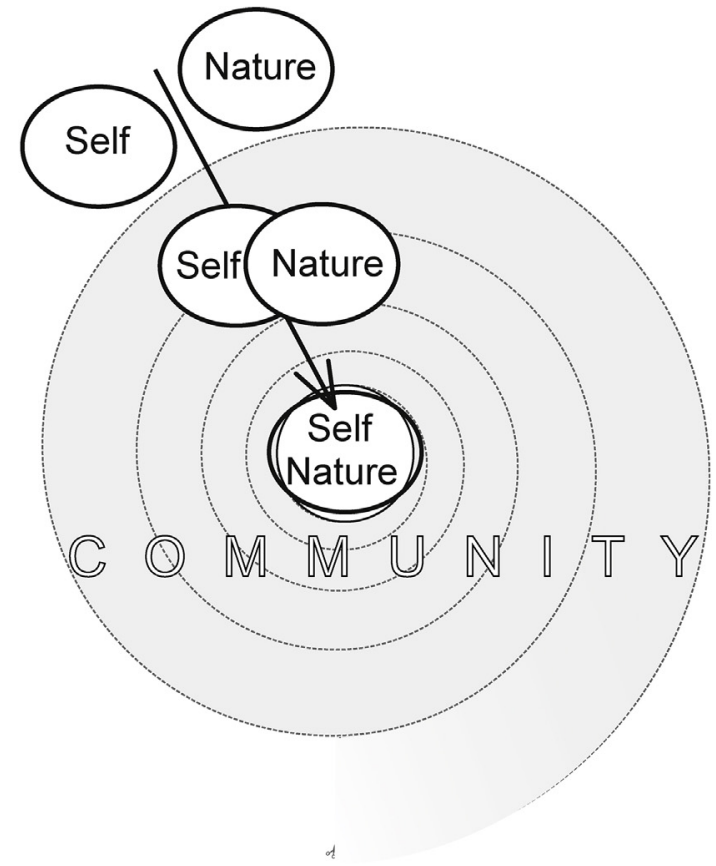

Fig. B2. Interconnectedness indicator.

This indicator gives insights about the changes that took place along the process and about the strength of interplay between personal reflection and action-oriented outreach. It is assumed that the deeper the personal experience is the stronger the commitment to participate in further actions for sustainability.

\section{Guiding questions:}

Inward pointing arrows: Consider the process you have been part of. To what level of depth has the process taken you with regard on a) deep listening, b) personal reflection, c) experiencing interconnectedness, d) commitment?

$\Longrightarrow$ The closer the participant positions her/himself on each one of the four arrows towards the center, the deeper she/he has experienced the space provided in the process for reflection, listening, interconnection and commitment.

Outward pointing arrows: Consider the process you have been part of. To what extent has the process taken you with regard on e) motivation to reach out for change, f) motivation to connect with others, g) personal growth, f) community growth?

$\Longrightarrow$ The farer out the participant positions her/himself on each one of the four arrows, the larger the extent on personal growth, motivation to reach out for change, motivation to connect with others and on community growth.

\section{Possible measurement:}

(i) Individual mapping on prepared sheet, or

(ii) Group mapping (prepared sheet on a wall where participants can use sticky dots).

Each participant is requested to mark her/his position on each one of the eight arrows. Preferably, a time perspective is included (e.g. indicate the position at the beginning and at the end of the process)

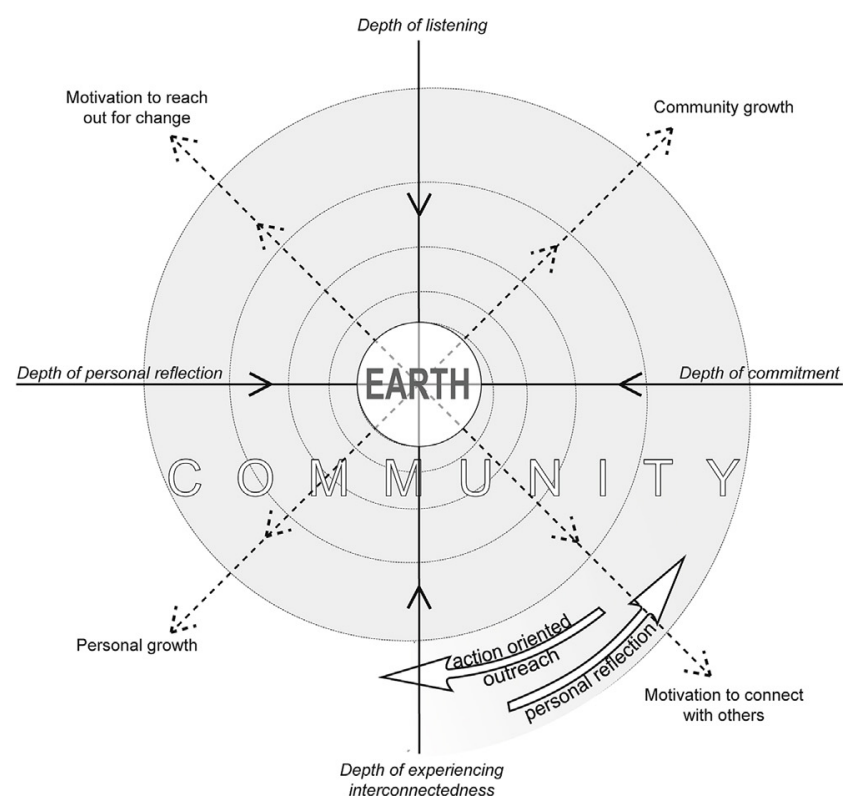

Fig. B3. Transformation-compass indicator.

\section{Appendix B. Supplementary data}

Supplementary data associated with this article can be found, in the online version, at http://dx.doi.org/10.1016/j.ecolind.2015. 11.057 .

\section{References}

AASHE, 2014a. Governance. In: AASHE (Ed.), STARS 2.0. Technical Manual. AASHE, Philadelphia, http://www.aashe.org/files/documents/STARS/2.0/stars . 2.0.2_credit_pa_3.pdf (1.07.15).

AASHE, 2014b. STARS 2.0 Technical Manual, Retrieved from: https://stars.aashe.org/ pages/about/technical-manual.html (15.07.15).
Adomssent, M., Godemann, J., Michelsen, G.,2008. Sustainable University - empirical evidence and strategic recommendations for holistic transformation approaches to sustainability in higher education institutions. In: Proceedings of the 4th International Barcelona Conference on Higher Education. Paper Presented at the Higher Education for Sustainable Development, Barcelona.

Argyris, C., Schoen, D.A., 1978. Organizational Learning: A Theory of Action Perspective. Addison-Wesley, Reading, MA.

Argyris, C., Schoen, D.A., 1996. Organizational Learning II. Theory, Method, and Practice. Assison-Wesley, Redwood City, CA.

Baan, C., Long, P., Pearlman, D., (MA Master-thesis) 2011. Cultivating personal leadership capacities to facilitate collaboration in Strategic Sustainable Development. Blekinge Institute of Technology, Karlskrona, Sweden, Retrieved from: http://www.bth.se/fou/cuppsats.nsf/all/ 21e8a0418502eb8ec12578be00480a8f?OpenDocument.

Barth, M., 2013. Many roads lead to sustainability: a process-oriented analysis of change in higher education. Int. J. Sustain. High. Educ. 14 (2), 160-175, http:// dx.doi.org/10.1108/14676371311312879. 
Barth, M., 2015. Implementing Sustainability in Higher Education: Learning in an Age of Transformation. Routledge, New York.

Barth, M., Michelsen, G., 2013. Learning for change: an educational contribution to sustainability science. Sustain. Sci. 8 (1), 103-119, http://dx.doi.org/10.1007/ s11625-012-0181-5.

Barth, M., Rieckmann, M., 2012. Academic staff development as a catalyst for curriculum change towards education for sustainable development: an output perspective. J. Clean. Prod. 26, 28-36, http://dx.doi.org/10.1016/j.jclepro.2011. 12.011.

Bell, S., Morse, S., 2008. Sustainability Indicators - Measuring the Immeasurable? Earthscan, London.

Beringer, A., Adomßent, M., 2008. Sustainable university research and development: inspecting sustainability in higher education research. Environ. Educ. Res. 14(6), 607-623, http://dx.doi.org/10.1080/13504620802464866.

Beyer, C., 2013. Spirals, Retrieved from: http://altreligion.about.com/od/symbols/a/ Spirals.htm (01.07.14).

Bond, A.J., Morrison-Saunders, A., 2011. Re-evaluating sustainability assessment: aligning the vision and the practice. Environ. Impact Assess. Rev. 31 (1), 1-7, http://dx.doi.org/10.1016/j.eiar.2010.01.007.

Bormann, I., 2007. Criteria and indicators as negotiated knowledge and the challenge of transfer. Educ. Res. Policy Pract. 6(1), 1-14, http://dx.doi.org/10.1007/s10671007-9015-0.

Brinkhurst, M., Rose, P., Maurice, G., Ackerman, J.D., 2011. Achieving campus sustainability: top-down, bottom-up or neither? Int. J. Sustain. High. Educ. 12 (4), 338-354.

Cebrián, G., Grace, M., Humphris, D., 2013. Organisational learning towards sustainability in higher education. Sustain. Account. Manage. Policy J. 4 (3), 285-306.

Cooperrider, D.L., Whitney, D., Stavros, J.M., 2008. Appreciative Inquiry Handbook: For Leaders of Change. Berret-Koehler Publishers, San Francisco.

Copernicus Alliance, 2012. Rio+20 Treaty on Higher Education. http://hetreatyrio20. com/wordpress/wp-content/uploads/2013/06/treaty_rio.pdf.

Cortese, A.D., 2003. The Critical Role of Higher Education in Creating a Sustainable Future. Planning for Higher Education, Retrieved from: http://www.aashe.org/ documents/resources/pdf/Cortese_PHE.pdf (02.11.11).

Cousins, J.B., Chouinard, J.A., 2012. Participatory Evaluation Up Close: An Integration of Research-based Knowledge. Information Age Publishing.

Cousins, J.B., Whitmore, E., 1998. Framing participatory evaluation. New Dir. Eval. 1998 (80), 5-23, http://dx.doi.org/10.1002/ev.1114.

Dahl, A.L., 2012. Achievements and gaps in indicators for sustainability. Ecol. Indic. $17,14-19$.

Dewey, J., 1916. Democracy and Education. An Introduction to the Philosophy of Education. Macmillan, New York.

Di Giulio, A., Schweizer, C.R., Adomssent, M., Blaser, M., Bormann, I., Burandt, S., Fischbach, R., Kaufmann-Hoyoz, R., Krikser, T., David, C.K., Rammel, C., Streissler, A., 2012. Education on the path to sustainability. Proposal of an indicator set to evaluate education for sustainable development. In: Allgemeine Oekologie zur Diskussion gestellt (No. 13). University of Bern, Interdisciplinary Centre for General Ecology. (IKAO), Bern.

Disterheft, A., Azeiteiro, U.M., Leal Filho, W., Caeiro, S.S., 2015a. Participatory processes in sustainable universities - what to assess? Int. J. Sustain. High. Educ. 16 (5), http://dx.doi.org/10.1108/IJSHE-05-2014-0079.

Disterheft, A., Caeiro, S.S., Azeiteiro, U.M., Leal Filho, W., 2012. Implementing sustainability at the campus - towards a better understanding of participation processes within sustainability initiative (Ch. 29). In: Leal Filho, W. (Ed.), Sustainable Development at Universities: New Horizons. Peter Lang Scientific Publisher Frankfurt, pp. 345-361.

Disterheft, A., Caeiro, S.S., Azeiteiro, U.M., Leal Filho, W., 2013a. Challenges and opportunities for the assessment of participation processes in sustainable universities - toward the integration of a forgotten dimension. Paper Presented at the ERSCP-EMSU 2013 (June 04-07, 2013), Istanbul.

Disterheft, A., Caeiro, S.S., Azeiteiro, U.M., Leal Filho, W., 2013b. Sustainability science and education for sustainable development in universities - a critical reflection. In: Caeiro, S., Leal Filho, W., Azeiteiro, U.M., Chiappetta Jabbour, C.J. (Eds.), Sustainability Practices in Higher Education Institutions - Mapping Trends and Good Practice at Universities Round the World. Springer, London, UK, pp. 3-27.

Disterheft, A., Caeiro, S.S., Azeiteiro, U.M., Leal Filho, W., 2015b. Sustainable universities - a study of critical success factors for participatory approaches. J. Clean. Prod. 106, 11-21, http://dx.doi.org/10.1016/j.jclepro.2014.01.030.

Dlouhá, J., Barton, A., Janoušková, S., Dlouhý, J., 2013. Social learning indicators in sustainability-oriented regional learning networks. J. Clean. Prod. 49, 64-73, http://dx.doi.org/10.1016/j.jclepro.2012.07.023.

Doody, D.G., Kearney, P., Barry, J., Moles, R., O’Regan, B., 2009. Evaluation of the Q-method as a method of public participation in the selection of sustainable development indicators. Ecol. Indic., 1129-1137.

Dragon Dreaming International, 2014. Dragon Dreaming Project Design, Version 2.06, Retrieved from: http://www.dragondreaming.org/about-us/theinternational-e-book/.

Earth Charter Initiative, 2010. Earth Charter, Retrieved from: http://www. earthcharterinaction.org/invent/images/uploads/echarter_english.pdf.

ESD inds, 2011. The Development of Indicators and Assessment Tools for CSO Projects Promoting Values-based Education for Sustainable Development, Retrieved from: http://www.esdinds.eu (15.04.14).

Fadeeva, Z., Galkute, L., Mader, C., Scott, G., 2014a. Assessment for transformation higher education thrives in redefining quality systems. In: Zinaida, F., Laima, G., Clemens, M., Geoff, S. (Eds.), Sustainable Development and Quality Assurance in
Higher Education. Transformation of Learning and Society. Palgrave Macmillan, Houndsmill

Fadeeva, Z., Galkute, L., Mader, C., Scott, G. (Eds.), 2014b. Sustainable Development and Quality Assurance in Higher Education. Transformation of Learning and Society. Palgrave Macmillan, Houndsmill.

Fadeeva, Z., Mochizuki, Y., 2010. Higher education for today and tomorrow: university appraisal for diversity, innovation and change towards sustainable development. Sustain. Sci. 5 (2), 249-256, http://dx.doi.org/10.1007/s11625010-0106-0.

Fraser, E.D.G., Dougill, A.J., Mabee, W.E., Reed, M., McAlpine, P., 2006. Bottom up and top down: analysis of participatory processes for sustainability indicator identification as a pathway to community empowerment and sustainable environmental management. J. Environ. Manage. 78 (2), 114-127, http://dx.doi.org/ 10.1016/j.jenvman.2005.04.009.

Fung, A., 2006. Varieties of participation in complex governance. Public Adm. Rev. (December (Special issue)), 66-75.

Gaventa, J., Cornwall, A., 2006. Challenging the boundaries of the possible: participation, knowledge and power. IDS Bull. 37 (6), 122-128, http://dx.doi.org/10. $1111 / \mathrm{j} .1759-5436.2006$.tb00329.x.

Glasser, H., 2004. Learning our way to a sustainable and desirable world: ideas inspired by arne naess and deep ecology. In: Corcoran, P.B., Wals, A.E.J. (Eds.), Higher Education and the Challenge of Sustainability. Springer, Netherlands, pp. 131-148, http://dx.doi.org/10.1007/0-306-48515-X_11.

Glover, A., Peters, C., Haslett, S.K., 2011. Education for sustainable development and global citizenship - an evaluation of the validity of the STAUNCH auditing tool. Int. J. Sustain. High. Educ. 12 (2), 125-144.

Habermas, J., 1985. The Theory of Communicative Action, Volume 1: Reason and the Rationalization of Society. Beacon Press, Boston.

Hart, A., Wolff, D., 2006. Developing local 'communities of practice' through local community-university partnerships. Plan. Pract. Res. 21 (1), 121-138, http:// dx.doi.org/10.1080/02697450600901616.

Hedlund-de Witt, A., (Doctoral thesis) 2013. Worldviews and the transformation to sustainable societies. An exploration of the cultural and psychological dimensions of our global environmental challenges. Free University Amsterdam, Amsterdam, Retrieved from: http://dare.ubvu.vu.nl/handle/1871/ 48104? show=full.

Imran, S., Alam, K., Beaumont, N., 2014. Reinterpreting the definition of sustainable development for a more ecocentric reorientation. Sustain. Dev. 22 (2), 134-144, http://dx.doi.org/10.1002/sd.537.

Jones, D.R., 2012. Looking through the "greenwashing glass cage" of the green league table towards the sustainability challenge for UK universities. J. Organ. Change Manage. 25 (4), 630-647.

Jones, D.R., 2013. 'The Biophilic University': a de-familiarizing organizational metaphor for ecological sustainability? J. Clean. Prod. 48, 148-165, http://dx doi.org/10.1016/j.jclepro.2013.02.019.

Jongbloed, B., Enders, J., Salerno, C., 2008. Higher education and its communities. High. Educ. 56, 303-324, http://dx.doi.org/10.1007/s10734-008-9128-2.

Karatzoglou, B., 2013. An in-depth literature review of the evolving roles and contributions of universities to Education for Sustainable Development. J. Clean. Prod. 49, 44-53, http://dx.doi.org/10.1016/j.jclepro.2012.07.043.

Kellert, S.R., Wilson, E.O., 1995. The Biophilia Hypothesis. Island Press, Washington.

Koester, R.J., Eflin, J., Vann, J., 2006. Greening the campus: a whole systems approach. J. Clean. Prod 14 (9-11), 769-779.

Krasny, M.E., Delia, J., 2015. Natural area stewardship as part of campus sustainability. J. Clean. Prod., http://dx.doi.org/10.1016/j.jclepro.2014.04.019.

Læssøe, J., 2010. Education for sustainable development, participation and sociocultural change. Environ. Educ. Res. 16 (1), 39-57, http://dx.doi.org/10.1080/ 13504620903504016.

Lang, D.J., Wiek, A., Bergmann, M., Stauffacher, M., Martens, P., Moll, P., Swilling, M., Thomas, C.J., 2012. Transdisciplinary research in sustainability science: practice, principles, and challenges. Sustain. Sci. 7 (1), 25-43.

Lankester, E.R., 1903. Spirals in Art and Nature. John Murray, London.

Lauder, A., Sari, R.F., Suwartha, N., Tjahjono, G., 2015. Critical review of a global campus sustainability ranking: GreenMetric. J. Clean. Prod., http://dx.doi.org/ 10.1016/j.jclepro.2015.02.080.

Leal Filho, W., Manolas, E., Pace, P., 2015. The future we want: key issues on sustainable development in higher education after Rio and the UN decade of education for sustainable development. Int. J. Sustain. High. Educ. 16 (1), 112-129, http:// dx.doi.org/10.1108/IJSHE-03-2014-0036.

Leopold, A., 1949. A Sand County Almanac. Ballantine Books, New York.

Lidgren, A., Rodhe, H., Huisingh, D., 2006. A systemic approach to incorporate sustainability into university courses and curricula. J. Clean. Prod. 14 (9-11), 797-809.

Lozano, R., 2006. Incorporation and institutionalization of SD into universities: breaking through barriers to change. J. Clean. Prod. 14 (9-11), 787-796.

Lozano, R., Ceulemans, K., Alonso-Almeida, M., Huisingh, D., Lozano, F.J., Waas, T., Lambrechts, W., Lukman, R., Hugé, J., 2014. A review of commitment and implementation of sustainable development in higher education: results from a worldwide survey. J. Clean. Prod., http://dx.doi.org/10.1016/j.jclepro.2014.09. 048.

Lozano, R., Lukman, R., Lozano, F.J., Huisingh, D., Lambrechts, W., 2013. Declarations for sustainability in higher education: becoming better leaders, through addressing the university system. J. Clean. Prod. 48, 10-19, http://dx.doi.org/10. 1016/j.jclepro.2011.10.006. 
Macmillan Dictionary (Ed.), 2015. Macmillan Dictionary. Macmillan Publishers Limited, Retrieved from: http://www.macmillandictionary.com/dictionary/ british/transformation (22.07.15).

Macy, J., Brown, M., 2014. Coming Back to Life - The Updated Guide to the Work that Reconnects. New Society Publisher, Gabriola Island.

Mader, C., Scott, G., Razak, D.A., 2013. Effective change management, governance and policy for sustainability transformation in higher education. Sustain. Account. Manage. Policy J. 4 (3), 264-284, http://dx.doi.org/10.1108/SAMPJ-09-20130037.

Manzo, L.C., Perkins, D.D., 2006. Finding common ground: the importance of place attachment to community participation and planning. J. Plan. Lit. 20 (4), 335-350, http://dx.doi.org/10.1177/0885412205286160.

McEwen, L., Strachan, G., Lynch, K., 2010. 'Shock and Awe' or 'Reflection and Change': stakeholder perceptions of transformative learning in higher education. Learn. Teach. High. Educ. 5, 34-55.

Meadows, D.H., 1998. Indicators and Information Systems for Sustainable Development. Donella Meadows Institute (former Sustainability Institute), Vermont.

Mezirow, J., 1997. Transformative learning: theory to practice. New Dir. Adult Contin. Educ. 74, 5-12.

Mezirow, J., 1978. Perspective transformation. Adult Educ. Q. 28(2), 100-110, http:// dx.doi.org/10.1177/074171367802800202.

Mochizuki, Y., Fadeeva, Z., 2010. Competences for sustainable development and sustainability: significance and challenges for ESD. Int. J. Sustain. High. Educ. 11 (4), 391-403, http://dx.doi.org/10.1108/14676371011077603.

Moore, J., 2005. Is higher education ready for transformative learning?: a question explored in the study of sustainability. J. Transform. Educ. 3 (1), 76-91, http:// dx.doi.org/10.1177/1541344604270862.

Morrissey, J., 2000. Indicators of citizen participation: lessons from learning teams in rural EZ/EC communities. Community Dev. J. 35 (1), 59-74, http://dx.doi.org/ 10.1093/cdj/35.1.59.

Mueller-Christ, G., Liebscher, A.K., 2015. Advanced training for sustainability change agents - insights and experiences from a seminar using the method of systemic constellations. In: Leal Filho, W. (Ed.), Integrative Approaches to Sustainable Development at University Level. Springer International, Switzerland, pp. 451-466.

Muff, K. (Ed.), 2014. The Collaboratory. Greenleaf Publishing, Sheffield.

Mulà, I., (Ph.D., Doctoral thesis) 2011. Living and Learning Sustainability in Higher Education: Constructing indicators of social learning. University of Gloucestershire, Gloucestershire, Retrieved from: http://ethos.bl.uk/ OrderDetails.do?did=1\&uin=uk.bl.ethos.558756.

Naess, A., 2008. Self-realization: an ecological approach to being in the world. In: Drengson, A.R., Bill, D. (Eds.), The Ecology of Wisdom - Writings by Arne Naess. Counterpoint, Berkeley.

O’Brien, K., Reams, J., Caspari, A., Dugmore, A., Faghihimani, M., Fazey, I., Hackmann, H., Manuel-Navarrete, D., Marks, J., Miller, R., Raivio, K., Romero-Lankao, P., Virji, H., Vogel, C., Winiwarter, V., 2013. You say you want a revolution? Transforming education and capacity building in response to global change. Environ. Sci. Policy 28, 48-59, http://dx.doi.org/10.1016/j.envsci.2012.11.011.

Orr, D., 2002. The Nature of Design: Ecology Culture and Human Intention. Oxford University Press, New York.

Orr, D.W., 2004. Earth in Mind: On Education, Environment and the Human Prospect, 10th anniversary ed. Island Press, Washington.

Parker, J., 2010. Competencies for interdisciplinarity in higher education. Int. J. Sustain. High. Educ. 11 (4), 325-338.

Phillips, A., 2009. Institutional transformations. In: Arran, S. (Ed.), The Handbook of Sustainability Literacy. Green Books Ltd., Totnes, pp. 209-214.

Presencing Institute, 2015. Tools, Retrieved from: https://http://www.presencing. com/tools (01.07.15).

Pugh, K.J., Linnenbrink-Garcia, L., Koskey, K.L.K., Stewart, V.C., Manzey, C., 2010. Motivation, learning, and transformative experience: a study of deep engagement in science. Sci. Educ. 94 (1), 1-28, http://dx.doi.org/10.1002/sce.20344.

Ramos, T.B., Caeiro, S.S., 2010. Meta-performance evaluation of sustainability indicators. Ecol. Indic. 10 (2), 157-166

Reed, M.S., Fraser, E.D.G., Dougill, A.J., 2006. An adaptive learning process for developing and applying sustainability indicators with local communities. Ecol. Econ. 59 (4), 406-418, http://dx.doi.org/10.1016/j.ecolecon.2005.11.008.

Reed, M.S., Graves, A., Dandy, N., Posthumus, H., Hubacek, K., Morris, J., Prell, C., Quinn, C.H., Stringer, L.C., 2009. Who's in and why? A typology of stakeholder analysis methods for natural resource management. J. Environ. Manage. 90 (5), 1933-1949, http://dx.doi.org/10.1016/j.jenvman.2009.01.001.

Reid, A., Nikel, J., Scott, W., 2006. Indicators for Education for Sustainable Development: A Report on Perspectives, Challenges and Progress. Centre for Research in Education and the Environment (University of Bath), Bath, Available at http://www.agf.org.uk/cms/upload/pdfs/CR/2006_CR1515_e_education_ for_sustainable_development.pdf.

Rieckmann, M., 2012. Future-oriented higher education: which key competencies should be fostered through university teaching and learning? Futures 44 (2), 127-135, http://dx.doi.org/10.1016/j.futures.2011.09.005.

Rode, H., Michelsen, G., 2008. Levels of indicator development for education for sustainable development. Environ. Educ. Res. 14 (1), 19-33, http://dx.doi.org/ $10.1080 / 13504620701843327$.

Roorda, N., 2001. In: Roorda, N. (Ed.), Auditing Instrument for Sustainability in Higher Education. , Retrieved from: http://www.eauc.org.uk/audit_instrument for_sustainability_in_higher_educ.
Rosenberg, M.B., 2003. Non-violent Communication, 2nd ed. Puddle Dancer Press Encinitas.

Roszak, T., 2001. The Voice of the Earth: An Exploration of Ecopsychology. Phanes Press.

Sandfort, J., Quick, K.S., 2015. Building deliberative capacity to create public value the practices and artifacts of the art of hosting. In: Bryson, J., Bloomber, L., Crosby B. (Eds.), Public Administration and Public Value. Georgetown University Press, Washington, DC, pp. 39-52.

Santana-Medina, N., Franco-Maass, S., Sánchez-Vera, E., Imbernon, J., Nava-Bernal, G., 2013. Participatory generation of sustainability indicators in a natural protected area of Mexico. Ecol. Indic. 25, 1-9, http://dx.doi.org/10.1016/j.ecolind. 2012.09.002.

Scharmer, C.O., 2008. Theory U. Leading from the Future as it Emerges. Presencing Institute, Cambridge.

Schultz, P.W., 2002. Inclusion with nature: the psychology of human-nature relations. In: Schmuck, P., Schultz, P.W. (Eds.), Psychology of Sustainable Development. Kluwer Academic Publisher, Norwell, pp. 61-78.

Schwarzin, L., Wals, A.E.J., Ateljevic, I., 2012. Collaborative curriculum innovation as a key to sprouting transformative higher education for sustainability. In GUNI (Ed.), In: Higher Education in the world 4. HIgher Education's Commitment to Sustainability: from Understanding to Action, vol. 1. GUNI, Hampshire, pp. 230-234.

Seeds for Change, 2013. A Consensus Handbook. Seeds for Change Lancaster Cooperative Ltd, Lancaster.

Seeley, T.D., 2010. Honeybee Democracy. Princeton University Press, Princeton.

Sharp, L., 2002. Green campuses: the road from little victories to systemic transformation. Int. J. Sustain. High. Educ. 3 (2), 128-145.

Shiva, V., 2005. Earth Democracy. ZED Books Ltd, London.

Sipos, Y., Battisti, B., Grimm, K., 2008. Achieving transformative sustainability learning: engaging head, hands and heart. Int. J. Sustain. High. Educ. 9 (1), 68-86.

Stephens, J.C., Graham, A.C., 2010. Toward an empirical research agenda for sustainability in higher education: exploring the transition management framework. J. Clean. Prod. 18 (7), 611-618.

Sterling, S., 2012. The Future Fit Framework. The Higher Education Academy, Hes lington, Available at https://http://www.heacademy.ac.uk/sites/default/files/ Future_Fit_270412_1435.pdf.

Sterling, S., 2005. Higher education, sustainability, and the role of systemic learning In: Corcoran, P.B., Wals, A.E.J. (Eds.), Higher Education and the Challenge of Sustainability. Springer, Netherlands, pp. 49-70, http://dx.doi.org/10.1007/0-30648515-X_5.

Sterling, S., 2011. Transformative lerning and sustainability: sketching the conceptual ground. Learn. Teach. High. Educ. 5, 17-33.

Taylor, A., Enggass, K., 2009. Linking Architecture and Education: Sustainable Design for Learning Environments. University of New Mexico Press.

Thompson, D.F., 2010. Representing future generations: political presentism and democratic trusteeship. Crit. Rev. Int. Soc. Polit. Philos. 13 (1), 17-37, http://dx. doi.org/10.1080/13698230903326232.

Tilbury, D., 2007. Monitoring and evaluation during the UN Decade of Education for Sustainable Development. J. Educ. Sustain. Dev. 1 (239), http://dx.doi.org/10. $1177 / 097340820700100214$.

Tilbury, D., 2011. Education for Sustainable Development. An Expert Review of Processes and Learning. UNESCO, Paris, Available at http://www.desd.org/Expert Revie_of_processes_and_learning_for_ESD.pdf.

UCLA Mindful Awareness Research Center, 2015. UCLAR Mindful Awareness Research Center, Retrieved from: http://marc.ucla.edu/default.cfm (15.07.15).

UE4SD, 2014. University Educators for Sustainable Development, Retrieved from: http://www.ue4sd.eu (02.03.15).

UNESCO, 2014. UNESCO Roadmap for Implementing the Global Action Programme on Education for Sustainable Development. UNESCO, Paris, Retrieved from: http://unesdoc.unesco.org/images/0023/002305/230514e.pdf.

Virgo, M., Wensing, E., Mason, G., Hurth, V., 2015. The key role of group facilitation in the collaborative social pedagogy necessary for deliberate social transformations toward global sustainability. In: Lynne, W. (Ed.), Education for Sustainable Development Pedagogy: Criticality, Creativity, and Collaboration. PedRIO Occasional Papers, vol. 8. Pedagogic Research Institute and Observatory (PedRIO) Plymouth, pp. 11-14

Wals, A.E.J.2010. Between knowing what is right and knowing that is it wrong to tell others what is right: on relativism, uncertainty and democracy in environmenta and sustainability education. Environ. Educ. Res. 16 (1), 143-151, http://dx.doi. org/10.1080/13504620903504099.

Walters, J., 2005. Fostering a culture of deep inquiry and listening. J. Qual. Particip. $28(2), 4-6$

Wenger, E., Trayner, B., de Laat, M., 2011. Promoting and Assessing Value Creation in Communities and Networks: A Conceptual Framework. Ruud de Moor Centrum, Open University Netherlands, Heerlen.

Wilson, E.O., 1984. Biophilia. Harvard University Press, Cambridge.

Yarime, M., Trencher, G., Mino, T., Scholz, R., Olsson, L., Ness, B., Frantzeskaki, N., Rotmans, J., 2012. Establishing sustainability science in higher education institutions: towards an integration of academic development, institutionalization and stakeholder collaborations. Sustain. Sci. 7, 101-113, http://dx.doi.org/10. 1007/s11625-012-0157-5.

Zelenski, J.M., Nisbet, E.K., 2014. Happiness and feeling connected: the distinct role of nature relatedness. Environ. Behav. 46 (1), 3-23, http://dx.doi.org/10.1177/ 0013916512451901. 